Sains Malaysiana 48(9)(2019): 1811-1821

http://dx.doi.org/10.17576/jsm-2019-4809-02

\title{
Contribution of Rice Fields to Bird Diversity in Peninsular Malaysia
}

(Sumbangan Sawah Padi kepada Kepelbagaian Burung di Semenanjung Malaysia)

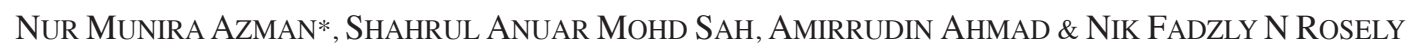

ABSTRACT

There is a lack of documentation on rice fields as an important habitat that harbour different bird diversity compared to natural habitats in Peninsular Malaysia. This study investigated the contribution of rice fields to bird diversity in Peninsular Malaysia. A total of 83 rice fields and 53 natural habitats throughout Peninsular Malaysia were included in this study. Birds were observed and counted using point-count and mist-netting methods. A total of 10,707 bird-sightings, with rice fields, recorded 129 species from 15 orders and 50 families from October 2013 to December 2014; whilst natural forests recorded a total of 438 species from 14 order and 59 families from February 1992 to January 2015. Diversity $t$-test showed a significant difference in the species richness between the two different habitats $(t=11.009, p<0.05)$. The high values of $\Delta^{+}$and $\Lambda^{+}$in many areas of rice fields were significantly influenced by the presence of waterbirds, albeit low species richness. This temporary wetland habitat harbours land birds and waterbirds in one place. The data presented here suggest that waterbirds and migratory birds in rice fields contribute significantly to the total bird species found in Peninsular Malaysia.

Keywords: Bird diversity; natural habitats; rice fields; taxonomic variation

\section{ABSTRAK}

Tidak banyak kajian yang telah dijalankan untuk mengenal pasti sawah padi sebagai habitat penting yang mampu menempatkan kepelbagaian burung yang berbeza berbanding habitat semula jadi di Semenanjung Malaysia. Kajian ini bertujuan mengetahui sumbangan sawah padi terhadap kepelbagaian burung di Semenanjung Malaysia. Sejumlah 83 tapak kajian sawah padi dan 53 habitat semulajadi di seluruh Semenanjung Malaysia telah dikaji. Burung diperhatikan dan dihitung dengan menggunakan kaedah titik kiraan dan jaring kabut. Sejumlah 10, 707 cerapan burung, dengan sawah padi merekodkan 129 spesies daripada 15 order dan 50 famili dari Oktober 2013-Disember 2014; manakala habitat semula jadi merekodkan sejumlah 438 spesies daripada 14 order dan 59 famili dari Februari 1992-Januari 2015. Ujian 'kepelbagaian t' menunjukkan perbezaan bererti dalam bilangan spesies antara dua habitat yang berbeza $(t=11.009$, $p=<0.05)$. Nilai $\Delta^{+}$dan $a^{+}$yang tinggi dalam kebanyakan kawasan sawah padi adalah bererti dan amat dipengaruhi oleh burung air walaupun bilangan spesies di sawah padi adalah rendah. Habitat tanah lembab sementara ini mampu menempatkan burung daratan dan air dalam satu kawasan. Hasil kajian mencadangkan burung air dan hijrah di sawah padi memberi sumbangan yang bererti kepada kepelbagaian burung yang diperhatikan di Semenanjung Malaysia.

Kata kunci: Habitat semula jadi; kepelbagaian burung; sawah padi; variasi taksonomi

\section{INTRODUCTION}

Peninsular Malaysia has many natural habitats, but its landscape also includes numerous agro-plantation areas such as rice fields. Rice fields are part of the traditional landscape synonymous with panoramic views in village areas of Peninsular Malaysia. The past few years have witnessed a growing number of published literature on birds in rice fields (Mohd-Taib \& Kamaruddin 2018; Nur Munira et al. 2014a, 2014b; Zainul-Abidin et al. 2017). Rice field is a temporary wetland that has great potential in supporting various waterbirds species (Nur Munira et al. 2014a). There are about 689,700 ha of rice field areas in Malaysia, with 501,090 ha located in Peninsular Malaysia (Department of Statistics 2015). Kedah devotes the most land area to rice production (210,327 ha), followed by Perak, Kelantan, and Perlis, while Negeri Sembilan has the smallest rice field areas (1,986 ha) (Department of Statistics 2013). Studies of birds in rice fields are constantly increasing worldwide. The importance of rice fields as temporary wetlands for birds has been well-documented in multiple areas such as USA, Europe, Korea, Japan, and India (Elphick 2008; Fujioka et al. 2010; Lourenço \& Piersma 2009; Sundar \& Subramanya 2010). In Malaysia, few studies have highlighted the importance of rice fields in relation to bird diversity. Studies by Nur Munira et al. (2014a, 2014b) have shown that rice growing seasons often influenced the diversity and abundance of birds in rice fields. A recent study on birds in rice fields of East Peninsular Malaysia found that different types of carnivorous and insectivores bird species serve as biological control agents against pest (Mohd-Taib \& Kamaruddin 2018). Therefore, evaluating 
the potential for man-made habitats as an essential refuge for birds and surrogates in replacing natural habitats is a key issue in conservation biology.

A previous study in Peninsular Malaysia has shown that different stages of rice fields are used by different groups of birds throughout the year (Nur Munira et al. 2014a). It is hypothesised that rice fields can accommodate birds from a different set of taxa compared to natural habitats, and rice fields may be an important contributor to the high diversity of birds in Peninsular Malaysia (Nur Munira et al. 2014a, 2011). The bird diversity of rice fields in Peninsular Malaysia has not yet been properly documented due to a lack of awareness among local researchers. Human activities such as pesticide use during rice growing seasons and converting rice fields into residential areas could negatively affect bird diversity (Nur Munira et al. 2014a). To the best of our knowledge, no specific research has evaluated the contribution of rice fields to total bird richness in Peninsular Malaysia. Natural habitats contributed high species richness of bird in Malaysia, but it is expected that rice fields also contribute a significant number of bird species in Peninsular Malaysia. It is because some bird species in rice fields are habitatdependent (Mohd-Taib \& Kamaruddin 2018; Nur Munira et al. 2014a).

The objective of this study was to examine the species richness and taxonomic composition of bird taxa in natural and rice field habitats of Peninsular Malaysia. Natural habitats have been chosen as a comparison because it is a representative of the habitat that contributes to the most species of birds in Peninsular Malaysia. The null hypothesis is that any species present at any study area has an equal probability of existing in all study areas (Leonard et al. 2006). It was predicted that rice fields would exhibit different groups of birds than natural habitats. This finding will probably contribute significant bird groups to the total bird diversity in Peninsular Malaysia.

\section{MATERIALS AND METHODS}

\section{STUDY AREA}

The data were collected from 53 natural habitat sites and 83 rice fields throughout Peninsular Malaysia (Figure 1). Every natural habitat site has a unique history, vegetation (e.g. primary forest, secondary forest, mangrove, and montane forest), and diversity. Rice fields were situated mostly in large granary areas of Peninsular Malaysia (i.e. MADA, KADA, IADA KSM, IADA BLS, IADA Penang, IADA Seberang Perak, and IADA KETARA). The rice growing season differs across study sites due to several factors such as variations in water level because of rainfall and drainage, as some fields are moist, have water in ditches, or are flooded or completely dried out. All the rice fields visited were surrounded by several habitat types such as oil palm plantations, forest patches, residential areas, roads, mangroves, and shorelines.

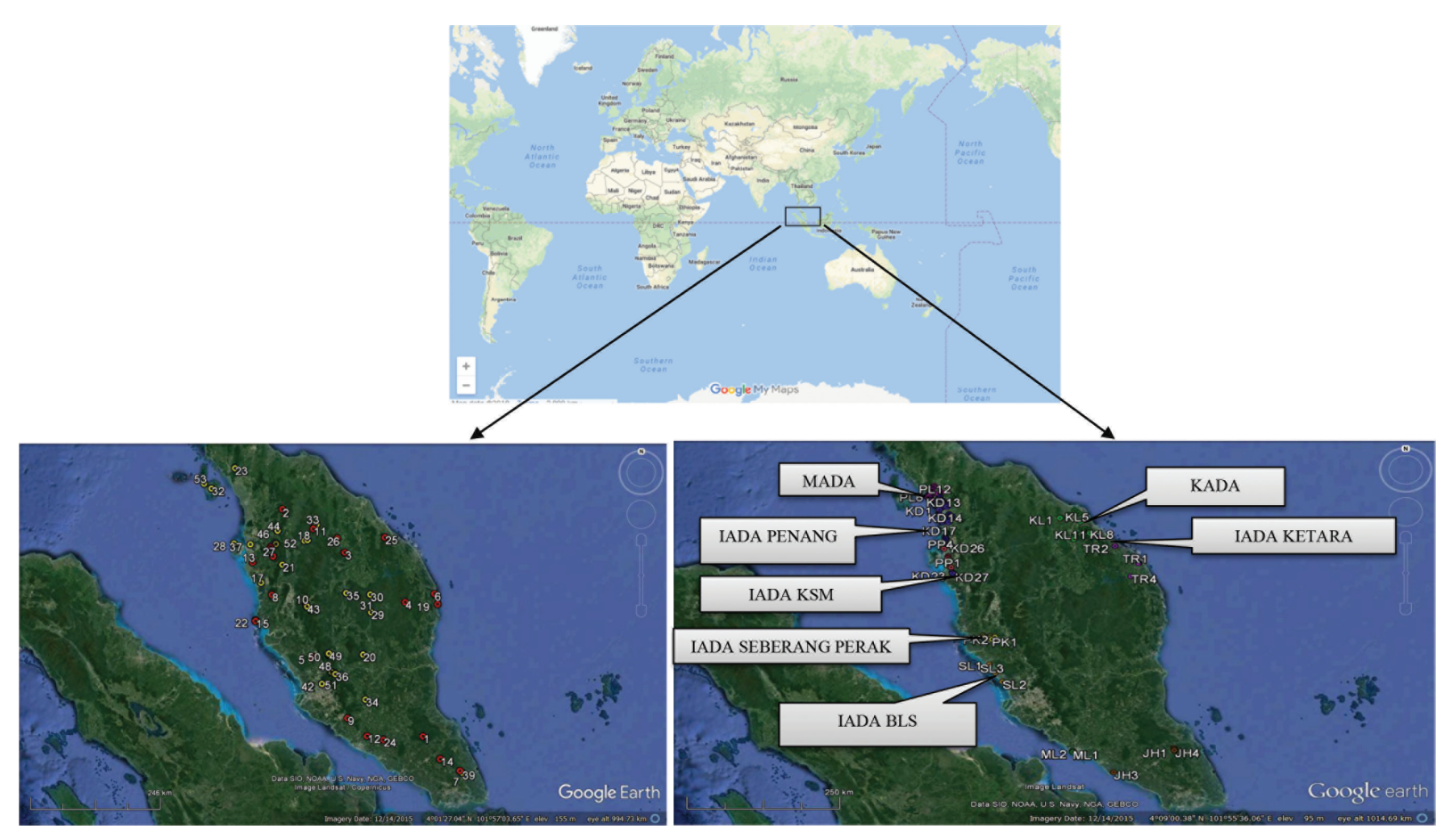

FIGURE 1. (a) World Map; the location of Peninsular Malaysia is shown in black box (b) Location of 53 study sites of natural habitats in Peninsular Malaysia (c) Location of 83 study sites of rice fields in Peninsular Malaysia. Most of rice fields are located in the granary areas (except ML, JH, and TR) namely MADA, IADA Penang, IADA KSM, IADA Seberang Perak, IADA BLS, KADA, and IADA KETARA. KD: Kedah, PL: Perlis, PP: Penang, PK: Perak, SL: Selangor, KL: Kelantan, TR: Terengganu, ML: Melaka, and JH: Johor Bahru 


\section{SAMPLE COLLECTION AND ANALYSIS}

Data collection were derived from primary and secondary sources. Primary data were collected monthly over four consecutive days, while secondary data were obtained from an e-bird database (http://ebird.org/content/ebird/) and published literature (Ginny-Ng et al. 2005; Mansor \& Sah 2012; Noramly \& Kumar 2005; Smith et al. 1995). Surveys began early in the morning (30 min after sunrise until $1100 \mathrm{~h}$ ) and late evening from 13:00 h to 19:00 h. Birds in flight were not recorded, except the Accipitridae, Apodidae, Hemiprocnidae and Hirundinae families, since these birds rarely perch on trees (Amano et al. 2008). The observations were made using a digital camera, telescope (Nikon ED82), and binoculars (Omicron Estavia 8x40). Mist-netting was used only in natural habitats during sampling sessions. Three to four days of mist-netting were set up at natural habitats and rice fields during each sampling session. Ten nets were opened at 07:00 $\mathrm{h}$ and closed at 18:00 h. Mist-netting was not necessary for rice fields because the birds could be observed directly.

A Venn diagram was used to examine species overlap between natural habitats and rice fields. Nonmetric multidimensional scaling (nMDS, 3D graphic) was also presented based on Jaccard similarity index to demonstrate a better picture of the differences between bird communities among landscapes. It was predicted that birds in rice fields would make a significant contribution in bird assemblages' structure of Peninsular Malaysia as the species composition is relatively different compared to natural habitats. To verify this hypothesis, average taxonomic distinctness (AvTD, $\Delta^{+}$) and variation in taxonomic distinctness $\left(\operatorname{VarTD}, \Lambda^{+}\right.$) were calculated for all study areas, both in natural habitats and rice fields.
The advantage of using the taxonomic distinctness index is that it is not affected by unequal sample size (Warwick \& Clarke 1995). Nonmetric multidimensional scaling and average taxonomic distinctness were quantified using PRIMER6 (http://www.primer-e.com) software.

\section{RESULTS}

\section{SPECIES ACCUMULATION CURVE AND SPECIES} COMPOSITION ACROSS RICE FIELDS

One hundred and twenty-nine (129) bird species were recorded from 83 study areas of rice fields in Peninsular Malaysia (Figure 2). Species richness in the study areas varied between 2 (in KD13) and 57 (in PP2) (mean = 12). Initially, the species accumulation curve increased rapidly as many new sets of species were recorded. Then, the curve began to rise slowly when many more samples were added but did not reach asymptote towards the end of sampling (Figure 2).

A total of $30(23.26 \%)$ unique and $25(19.38 \%)$ duplicate bird species were recorded from the samples. Unique species gradually decreased towards the end of the sampling whilst duplicates still showed increments although in smaller numbers (Figure 2). If sampling sites were added, additional species would be obtained from rice fields. It was predicted that unique species would continue to decrease, while duplicates would meet at a point with unique species and decrease continuously.

A total of 10,707 birds' occurrence representing 129 species (Table 1) and 50 families were recorded from October 2013 to December 2014 in 83 sites of rice fields. The dominant family was Accipitridae, contributing 15 species of raptors, followed by Ardeidae with 13 species,

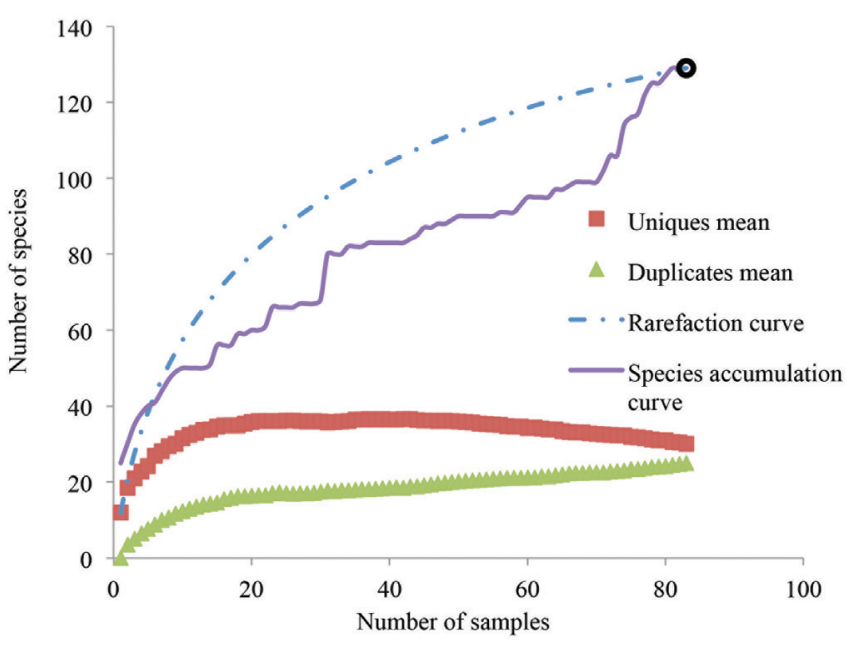

FIGURE 2. Species accumulation and rarefaction curve for bird species richness and their unique and duplicate occurrence from 83 rice fields of Peninsular Malaysia. The jagged line is the species accumulation curve for one of many possible orderings of 83 sites yielding a total of 129 bird species in rice field habitats. The smooth line is the sample-based rarefaction curve for the same data set, showing the mean number of species for all possible combinations of $1,2, \ldots, 83$ actual samples from the data set- this curve plots the species expected of the (sample-based) species accumulation curve.

The black hole indicates the total richness for all samples pooled. Red square and green triangles indicate the number of unique and duplicate occurrence of bird species in every sample from the data 
TABLE 1. Check list of bird in rice fields from 83 sampling sites in Peninsular Malaysia

\begin{tabular}{|c|c|c|c|c|}
\hline Family & Genus & Species & Common name & Occurrence \\
\hline \multirow[t]{15}{*}{ Accipitridae } & \multirow{2}{*}{ Accipiter } & gularis & Japanese Sparrowhawk & 2 \\
\hline & & soloensis & Chinese Sparrowhawk & 1 \\
\hline & \multirow[t]{3}{*}{ Aquila } & clanga & Greater Spotted Eagle & 5 \\
\hline & & heliaca & *Imperial Eagle & 3 \\
\hline & & nipalensis & $*$ Steppe Eagle & 2 \\
\hline & \multirow{4}{*}{$\begin{array}{l}\text { Butastur } \\
\text { Circus }\end{array}$} & indicus & Grey-faced Buzzard & 7 \\
\hline & & melanoleucos & *Pied Harrier & 7 \\
\hline & & Spesies 1 & $*$ Harrier sp. & 1 \\
\hline & & spilonotus & Eastern Marsh Harrier & 15 \\
\hline & Elanus & caeruleus & Black-shouldered Kite & 30 \\
\hline & Haliaeetus & leucogaster & *White-bellied Sea-eagle & 2 \\
\hline & Haliastur & indus & Brahminy Kite & 29 \\
\hline & Milvus & migrans & Black Kite & 14 \\
\hline & Pernis & ptilorhyncus & Oriental Honey Buzzard & 58 \\
\hline & Spilornis & cheela & Crested Serpent Eagle & 3 \\
\hline \multirow[t]{2}{*}{ Acrocephalinae } & Acrocephalus & orientalis & *Oriental Reed-warbler & 7 \\
\hline & Locustella & certhiola & Rusty-rumped Warbler & 10 \\
\hline Aegithinidae & Aegithina & tiphia & Common Iora & 2 \\
\hline \multirow{3}{*}{ Alcedinidae } & Alcedo & atthis & Common Kingfisher & 4 \\
\hline & Halcyon & smyrnensis & White-throated Kingfisher & 92 \\
\hline & Pelargopsis & capensis & Stork-billed Kingfisher & 6 \\
\hline Anatidae & Dendrocygna & javanica & *Lesser Whistling-duck & 78 \\
\hline Apodidae & Apus & affinis & House Swift & 4 \\
\hline \multirow[t]{13}{*}{ Ardeidae } & Ardea & alba & *Great Egret & 586 \\
\hline & & cinerea & *Grey Heron & 8 \\
\hline & & purpurea & *Purple Heron & 175 \\
\hline & Ardeola & bacchus & *Chinese Pond-heron & 9 \\
\hline & & sp. 1 & *Pond Heron sp. & 377 \\
\hline & & speciosa & *Javan Pond Heron & 1 \\
\hline & Bubulcus & coromandus & *Eastern Cattle Egret & 2950 \\
\hline & Butorides & striata & *Little Heron & 51 \\
\hline & Egretta & garzetta & *Little Egret & 2747 \\
\hline & Ixobrychus & cinnamomeus & *Cinnamon Bittern & 32 \\
\hline & & sinensis & *Yellow Bittern & 20 \\
\hline & Mesophoxy & intermedia & *Intermediate Egret & 217 \\
\hline & Nycticorax & nycticorax & *Black-crowned Night-heron & 79 \\
\hline Artamidae & Artamus & leucoryn & *White-breasted Wood Swallow & 3 \\
\hline Bucerotidae & Anthracoceros & albirostris & $*$ Oriental Pied Hornbill & 6 \\
\hline Caprimulgidae & Caprimulgus & macrurus & Large-tailed Nightjar & 20 \\
\hline \multirow[t]{4}{*}{ Charadriidae } & Charadrius & dubius & *Little Ringed Plover & 17 \\
\hline & & hiaticula & *Common-ringed Plover & 6 \\
\hline & & mongolus & $*$ Lesser Sand-plover & 7 \\
\hline & Pluvialis & fulva & *Pacific Golden Plover & 96 \\
\hline \multirow[t]{2}{*}{ Ciconiidae } & Anastomus & oscitans & Asian Openbill & 1072 \\
\hline & Leptoptilos & javanicus & *Lesser Adjutant & 9 \\
\hline \multirow[t]{2}{*}{ Cisticolidae } & Cisticola & juncidis & Zitting Cisticola & 34 \\
\hline & Orthotomus & sutorius & Common Tailorbird & 1 \\
\hline \multirow[t]{5}{*}{ Columbidae } & Columba & livia & Rock Pigeon & 55 \\
\hline & Geopelia & striata & Zebra Dove & 35 \\
\hline & Streptopelia & chinensis & $*$ Red-collared Dove & 6 \\
\hline & & chinensis & Spotted Dove & 117 \\
\hline & Treron & vernans & Pink-necked Green Pegion & 16 \\
\hline Coraciidae & Eurystomus & orientalis & Dollarbird & 5 \\
\hline
\end{tabular}


TABLE 1. Continued

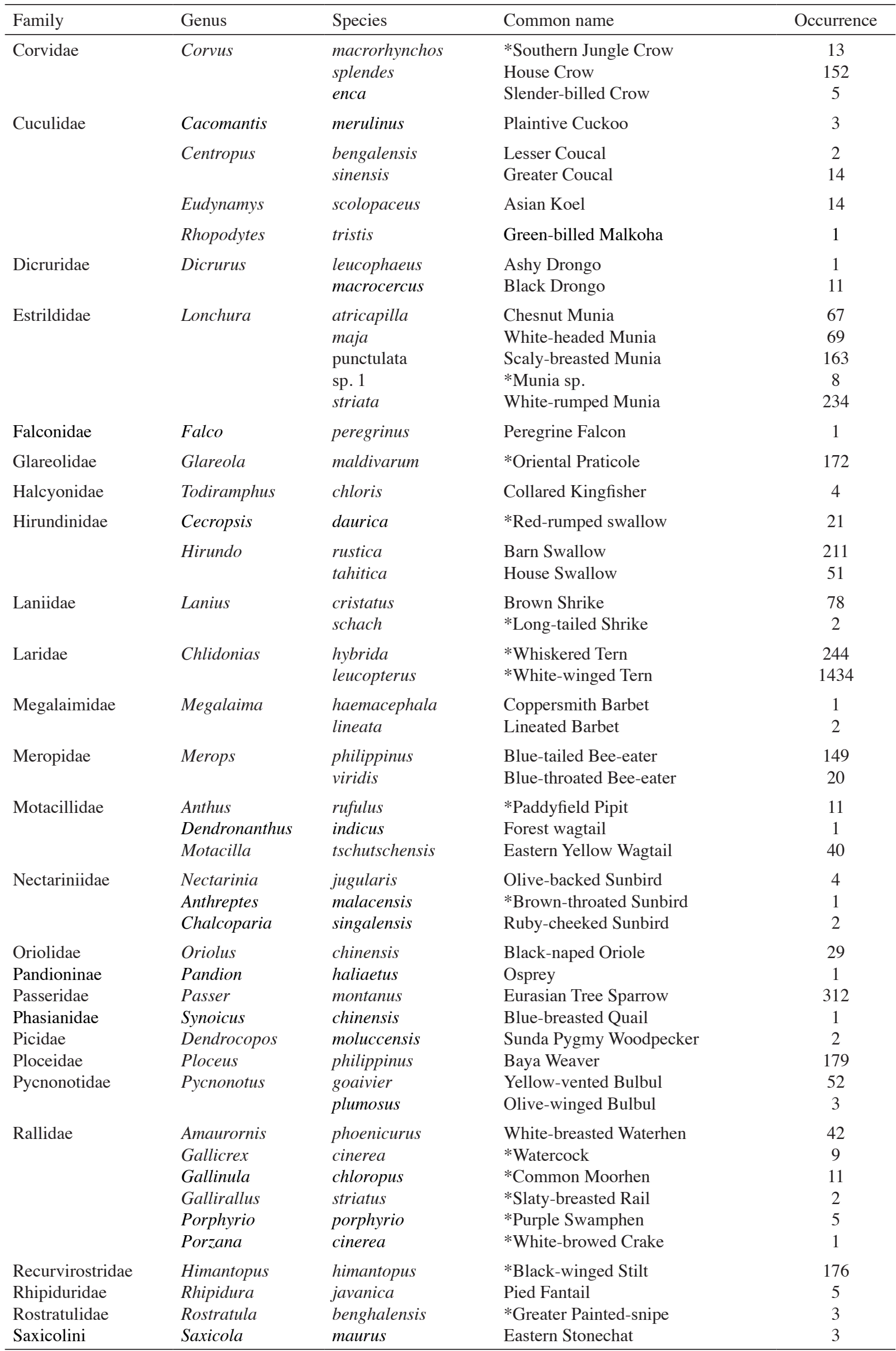


TABLE 1. Continued

\begin{tabular}{|c|c|c|c|c|}
\hline Family & Genus & Species & Common name & Occurrence \\
\hline \multirow[t]{5}{*}{ Scolopacidae } & Actitis & hypoleucos & *Common Sandpiper & 27 \\
\hline & Gallinago & gallinago & *Common Snipe & 1 \\
\hline & Snipe & sp. 1 & *Snipe sp. & 4 \\
\hline & Tringa & glareola & *Wood Sandpiper & 282 \\
\hline & & totanus & *Common Redshank & 28 \\
\hline \multirow[t]{6}{*}{ Sturdidae } & Acridotheres & cinereus & *White-vented Myna & 41 \\
\hline & & cristatellus & Crested Myna & 14 \\
\hline & & fuscus & Jungle Myna & 111 \\
\hline & & javanicus & Javan Myna & 146 \\
\hline & & tristis & Common Myna & 83 \\
\hline & Aplonis & panayensis & Asian Glossy Starling & 48 \\
\hline Sylviidae & Prinia & flaviventris & Yellow-bellied Prinia & 9 \\
\hline Timaliidae & Macronous & gularis & Pin-striped Tit-babbler & 2 \\
\hline \multirow[t]{4}{*}{ Tringinae } & Calidris & subminuta & *Long-toed Stint & 9 \\
\hline & Tringa & nebularia & *Common Greenshank & 6 \\
\hline & & stagnatilis & * Marsh Sandpiper & 3 \\
\hline & Xenus & cinereus & *Terek Sandpiper & 2 \\
\hline Turdidae & Copsychus & saularis & Oriental Magpie Robin & 13 \\
\hline Turnicidae & Turnix & suscitator & Barred Buttonquail & 2 \\
\hline Tytonidae & Tyto & alba & Common Barn-Owl & 1 \\
\hline \multirow[t]{2}{*}{ Vanellidae } & Vanellus & cinereus & Grey-headed Lapwing & 54 \\
\hline & & indicus & Red-wattled Lapwing & 35 \\
\hline
\end{tabular}

*Indicates bird species that only found in rice fields

and Rallidae and Sturnidae families with six species each. Among these, the three most common taxa were represented by the Ardeidae family, i.e. the Little Egret, Egretta garzetta (70 occurrences were recorded within 83 sites visited), Eastern Cattle Egret (64 occurrences), and Pond Heron sp., Ardeola sp. (44 occurrences). The existence of Ardeidae is very common in rice fields and easily recognised through their large-sized body, white, and frequently in large flocks. Four study areas recorded the highest number of Ardeidae with nine species recorded, including KD31: Pendang, PK5: Ulu Dedap, PP2: Kubang Semang, and JH4: Kahang Organic Rice Eco-Farm.

The Black-shouldered Kite (Elanus caeruleus) was frequently found with hovering behaviour during hunting activity. The Brahminy Kite (Haliastur indus) and the Black-shouldered Kite were the common resident raptors in rice fields. Migratory raptors including Chinese Sparrowhawk (Accipiter soloensis), Pied Harrier (Circus melanoleucos), and Black Kite (Milvus migrans) were also found in rice fields habitat. Study areas in Perak and Melaka (PK5: Ulu Dedap and MK1: Batang Tiga) recorded the highest observed number of raptors, i.e. six species each. Based on these observations, migratory raptors are usually present in rice fields between September and March throughout the year.

A total of 42 waterbirds species from 11 families were observed in the rice fields of Peninsular Malaysia. Other than Ardeidae (egrets and herons) and Rallidae (rails and crakes), waterbirds were also represented by the families of Charadriidae (four species of plovers), Ciconiidae (one species of adjutant and openbill), Laridae and Sternidae (three species of terns), Recurvirostridae (one species of stilt), Scolopacidae (four species of sandpipers, one species of green/redshank, two species of snipe, and one species of stint), Rostratulidae (one species of painted-snipe), Vanellidae (two species of lapwings), and Dendrocygnidae (one species of whistling-duck).

This study discovered Whiskered Tern (Chlidonias hybrid) in a large flock in KD15: Kg. Teluk Kechai, Kuala Kedah (estimated 400 individuals), KD17: Kg. Permatang Buloh, Yan (estimated 210 individuals), and PK4: Kg. Felda, Changkat Lada (estimated 146 individuals) during harvesting season in Kedah and rice growing season in Perak. There were also waterbirds that have unique occurrences in rice fields, i.e. Purple Swamphen (recorded in JH2: Kahang II), White-browed Crake (PP2: Kubang Semang), Common-ringed Plover (TR2: Kg. Permaisuri), Common Snipe (PP3: Bandar Perda), Marsh Sandpiper (ML2: Batang Tiga II), Terek Sandpiper, and Javan Pond Heron (JH1: Kahang 1).

\section{COMPARISON OF SPECIES COMMUNITY STRUCTURE IN NATURAL HABITATS AND RICE FIELDS}

In natural habitats, a total of 438 species (59 families) were recorded, while a total of 129 species (50 families) were recorded in the rice fields where the overlap of species between the two habitat types was considerable large (Figure 3). More than $50 \%$ of bird species found in the paddy fields environments were also found in natural 


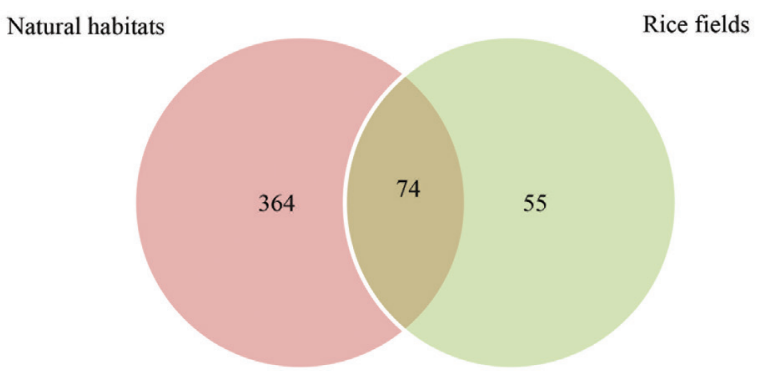

FIGURE 3. Number of species overlap among the two habitat types illustrated by Venn diagram. Rice fields contributed 55 species richness to the total checklist of natural habitats and rice fields (493)

habitats. Interestingly, when the two sets of data were further analysed, the diversity t-test, a measure based on Shannon's H' index, showed that species diversity of both habitat types was significantly different $(\mathrm{t}=11.01, p<0.05)$. The 3D nMDS ordination successfully separated study areas of rice fields and natural habitats into two groups based on bird composition (Figure 4, stress value $=0.12$ ). The results indicated that habitat types significantly dictated species occurrence. Similar habitat type of study areas contained similar species assemblages.

Taxonomic distinctness indices of average taxonomic distinctness (AvTD, $\Delta^{+}$) and variation in taxonomic distinctness (VarTD,$\Lambda^{+}$) were calculated using the presence/ absence data of birds from natural habitats and rice fields which are shown in Figure 5(a) and Figure 5(b), respectively. The site values of $\Delta^{+}$generally fell within $95 \%$ confidence funnel. Although study areas in the rice fields had recorded a low number of species compared with natural habitats, several study areas in rice fields scored a high value of delta plus.

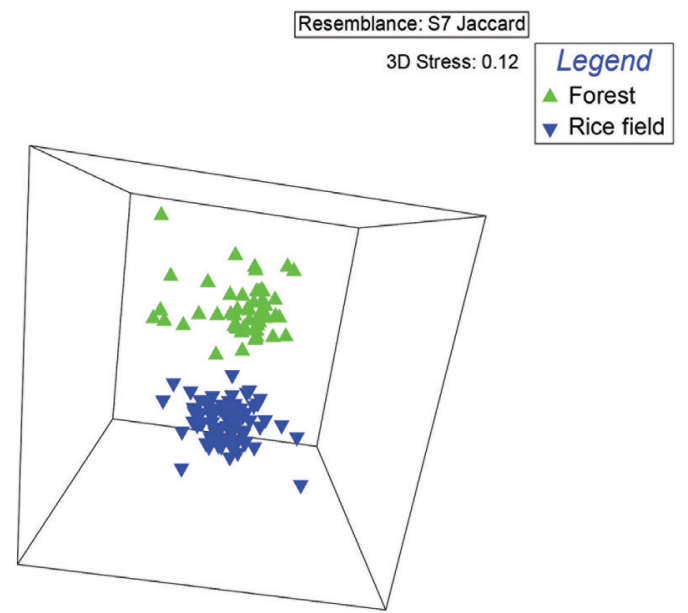

FIGURE 4. Three-dimensional nMDS configuration (Jaccard similarity measure) with stress value $=0.12$ showed that similar habitat type of study sites was grouped together indicating that it holds similar species as opposed to other habitat. ML2 and F9 were considered as outliers

A total of 24 and four study areas (Table 2) from natural habitats and rice fields, respectively, showed that their $\Delta^{+}$values fell outside the confidence limits of the $95 \%$ confidence funnel obtained from simulations (Figure 5(a)). This indicates that bird composition departs significantly from the null hypothesis of a random selection from the total species checklist. In other words, not every species in the total study areas (natural habitats and rice fields) has an equal probability of existing in all study areas. The high value of $\Delta^{+}$in many areas of rice fields proved that bird diversity was significantly diverse, i.e. species composition was made up of multi taxa influenced by the rice field species although species richness in rice fields a)

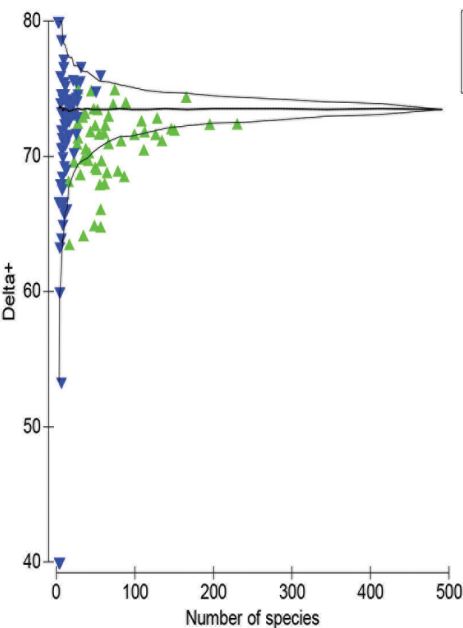

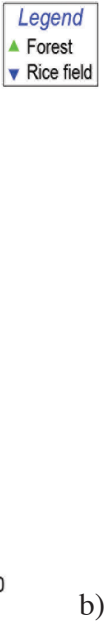

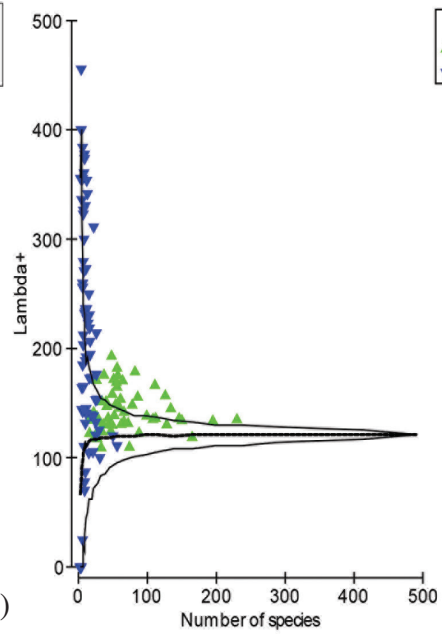

FIGURE 5. (a) Values of the average taxonomic distinctness $\left(\Delta^{+}\right)$for the bird communities of natural habitats and rice fields of Peninsular Malaysia, plotted against the number of species on the $95 \%$ confidence funnel. (b) Values of variation in taxonomic distinctness $\left(\Lambda^{+}\right)$for the bird communities of natural habitats and rice fields of Peninsular Malaysia, plotted against the number of species on the $95 \%$ confidence funnel. The dotted thin line in both graphs represent the 'expected' value of $\Delta^{+}$and $\Lambda^{+}$derived from a list of the 493 species recorded in this study 
TABLE 2. List of study areas fell outside the $95 \%$ confidence funnel of average taxonomic distinctness $\left(\Delta^{+}\right)$

\begin{tabular}{clcl}
\hline Codes & Location & Codes & Location \\
\hline F3 & Royal Belum A & F37 & Gunung Belumut \\
F5 & Merapoh & F39 & Inas \\
F9 & Gunung Ulu Kali & F41 & Belum-Temenggor (B) \\
F12 & Gunung Bintang & F43 & Kuala Lompat \\
F15 & Bukit Wang B & F44 & Lenggong \\
F16 & Bukit Wang A & F46 & Burma \\
F17 & Bukit Rengit & F48 & Ledang \\
F19 & Bukit Fraser B & F50 & Pergau \\
F25 & Ulu Muda & F51 & Ulu Selama \\
F26 & Gunung Stong & F52 & Teluk Kampi \\
F30 & Panti & KL2* & Kg. Sirap, Sg. Golok \\
F31 & Ulu Kenas & KL6* & Limbungan Pasir Puteh \\
F33 & Cameron Highlands B & KL10* & Kg. Pangkal Petai, Machang \\
F35 & Melaka & KL13* & Kg. Kepulau, Machang \\
\hline
\end{tabular}

* Indicates rice field study areas

was rather low. This is contributed by the high variation in taxonomic of birds from both habitat types.

Figure 5(b) similarly displays the value of the variation in taxonomic distinctness index and relates these to the 95\% limits for the simulated distribution of $\Lambda^{+}$from the random subsets of the total species list. This provides additional information about the biodiversity structure of the study areas in both natural habitats and rice fields. The measure of $\Lambda^{+}$separates few study areas of rice fields and more than half of the number of total study areas in natural habitats is distinctive, which was not able to be observed from the $\Delta^{+}$values. They fell above the upper limit of the $\Lambda^{+}$funnel, indicating that the variation in distinctness for these study areas was higher than expected.

\section{DISCUSSION}

The species accumulation curve showed that the number of species found in rice fields of Peninsular Malaysia was relatively high. It was expected that the number of species would have increased if the sampling duration is increased. Although the rarefaction curve did not reach an asymptote, the sampling was considered complete because the number of unique species had slowly decreased. If a few more samples were added, the number of duplicate species is predicted to decrease in parallel with the number of unique species. Previous studies have found that species richness in rice fields presents a greater diversity of birds than other agriculture areas such as oil palm and rubber plantations (Aratrakorn et al. 2006; Nur Munira et al. 2011).

Rice field is a man-made habitat that is mostly located adjacent to the lower streams in Peninsular Malaysia. This temporary wetland habitat continuously harbours land birds and waterbirds within one place (Razafimanjato et al. 2007; Zou et al. 2006). This unique habitat is primarily influenced by farming activities such as ploughing, planting, and harvesting. These activities are the main factors that influence bird use and bird occurrence in rice fields (Takahashi \& Ohkawara 2007; Wood et al. 2010). Activities like ploughing and harvesting increase the availability of food sources for birds. According to Nur Munira et al. (2014), each planting season attracts different bird species to the rice field.

Rice fields play a vital role as foraging grounds and stopover areas for both resident and migratory birds (King et al. 2010; Nur Munira et al. 2011). The present study found that most bird groups existing in rice fields were different from natural habitats. The widespread occurrences of Accipitrinidae, Ardeidae, Rallidae, and Sturnidae in rice fields were mostly influenced by food availability. In general, raptors could be easily detected when they are soaring and hunting in rice fields. The raptors of Accipitridae are believed to use rice fields as their favourite site for hunting preys. For example, raptors from the Accipitrinidae family prey on rodents and snakes in post-harvest areas of rice fields. This parallels the observations in studies undertaken in Southern Florida and Northern Peninsular Malaysia in which large numbers of raptors were found at recently harvested fields (Nur Munira et al. 2014b; Pearlstine et al. 2006). Meanwhile, during the migratory season, the number of raptors increases as more migratory raptor species are present in rice field areas.

Rice fields are highly synonymous with the existence of waterbirds. Waterbirds frequently occupy moist or flooded rice fields and forage either individually or in large flocks. Acosta et al. (2010) and Nur Munira et al. (2014a) have also shown that Ardeidae was commonly seen to forage behind tractors and harvesting machine because many invertebrates were exposed and become available to the birds. Through personal experience, during a ploughing activity, this unique habitat turns into 
a haven foraging ground which can accommodate more than hundreds of individual egrets and terns at one time since a great amount of invertebrate is available for them.

Rice fields were also identified to be used by threatened groups of birds, suggesting rice fields provide valuable man-made habitat. For example, endangered and vulnerable migratory species, i.e. Steppe Eagle, Imperial Eagle, and Greater Spotted Eagle can only be found in rice fields in higher densities than in natural forests since they use rice fields as their feeding ground and stopover areas. Masero et al. (2010) stated that most migratory raptors would utilise rice field areas along their migratory routes. Therefore, the high diversity of migratory birds (raptors and waterbirds) in rice fields indicates that the West Coast of Peninsular Malaysia is the main migratory route for both north and southbound species.

The existence of different bird taxa in rice fields, especially waterbirds has made a significant contribution to the species richness of birds in Peninsular Malaysia. Rice fields contribute 55 species to the total checklist of 493 birds in natural habitats and rice fields. Structurally, rice fields are open areas that are filled with paddy grass which are totally different from other monocultural areas (i.e. oil palm and rubber plantations). As expected, bird species richness and diversity in rice fields tend to be lower than natural habitats. However, rice fields are equally as important as natural habitats because these agriculture areas act as temporary wetlands that offer more feeding resources for waterbirds and migratory birds (Kelly 2008). Nonetheless, the high number of bird species recorded in rice fields is due to the greater presence of residents, rather than migratory birds.

The community ordination (nMDS) of the data obtained for both habitat types had shown a clear difference between bird communities in natural habitats and rice fields (Figure 4). The three-dimensional configuration showed distinctive patterns that indicate sites of similar habitat types were grouped. Only two study areas, the ML2 (Batang Tiga II, Melaka) and F9 (Gunung Ulu Kali), were located 'far' from their main group because both areas consist of infrequent bird composition compared to others. The ML2 recorded Long-toed Stint (Calidris subminuta), Common Greenshank (Tringa nebularia), Little-ringed Plover (Charadrius dubius), and Lesser Sand-plover (Charadrius mongolus). The presence of these shorebirds in ML2 rice fields was promoted by the existence of adjacent shoreline areas, natural ponds, and aquaculture ponds. This finding parallels the evidence provided by an earlier study in which shorebirds and wading birds were positively correlated with the number of habitat types adjacent to the rice field areas (Elphick 2008). The presence of shorebirds has made bird composition in ML2 quite different compared to other rice fields that are usually surrounded by orchards, forests, and residential areas. Meanwhile, bird composition in F9 included unique montane forest birds such as Mountain Bulbul (Hypsipetes mcclellandii), Golden-throated Barbet (Megalaima franklinii), and Golden Babbler (Stachyris chrysaea).
Previous biodiversity studies have used the taxonomic distinctness measures to analyse species community structure collected from different environmental gradients (Ellingsen et al. 2005) or different degree of anthropogenic effects (Guerrero et al. 2011). A similar concept was also applied in this study where these measures were used to observe the variation of bird taxonomy in rice fields and their contribution to the total bird diversity in Peninsular Malaysia. The combination of average and variation in taxonomic distinctness was instrumental since both indices were able to show the taxonomic relatedness patterns within an assemblage despite using the data in the form of presence/absence species checklist (Clarke \& Warwick 2001) and were collected from an unstandardised sampling method (Rogers et al. 1999).

In the present study, the distinction between the two habitats resulting from the different bird composition corresponds with a significant bird taxonomic variation. Taxonomic distinctness indices $\left(\Delta^{+}\right.$and $\left.\Lambda^{+}\right)$have confirmed a good degree of taxonomic variation in the communities of both habitat types based on bird taxonomic information. Most of the rice field study areas recorded a low number of species compared to natural habitats. However, they recorded high values of $\Delta^{+}$and $\Lambda^{+}$. The high score of delta plus in rice field resulted from the high taxonomic path length between the two randomly chosen species from the total species recorded (master list) (Bevilacqua et al. 2009; Clark \& Warwick 2001). This result indicated that bird diversity in Peninsular Malaysia had been significantly influenced by rice field habitats, although they harbour a low number of species compared to natural habitats. Thus, this study found that since rice fields were used as a foraging ground by a different group of bird taxa, they have contributed significantly to the bird species richness in Peninsular Malaysia.

High variation of bird taxa in rice fields is particularly important for bird diversity in Peninsular Malaysia. Natural habitats and rice fields were found to be significantly important for different groups of birds (Nur Munira et al. 2011). Both habitats are characterised by very different environmental conditions, vegetation structure, and with different intensity of human activities. The data presented here suggest that waterbirds and migratory birds in rice fields contribute to the total number of bird species found in Peninsular Malaysia. Rice field is known to play an important role in maintaining the existence of many species of waterbirds (Natuhara 2013). Although the existence of birds in rice fields is largely influenced by the rice growing season, the manipulation of flooding conditions in rice fields may help to increase the number of waterbirds and migratory birds in fields (Elphick \& Oring 2003). Thus, farming activities have an important relation towards bird patterns in rice fields.

Rapid encroachment resulted from the development of rice fields' surrounding is a primary concern, because the majority of rice fields are located near roads and surrounded by human settlements. The entire areas of rice field could be rapidly converted into residential areas, 
industrial sites, and roads. To avoid more rice fields being sold to developers, special campaigns can be conducted to create awareness among villagers (e.g. farmers and children) to protect or preserve habitats for the protected waterbirds and land birds in their backyard.

\section{CONCLUSION}

This study makes significant contributions to the current bird research in Malaysia as it has successfully produced valuable findings on bird species composition and assemblage structure in natural habitats and rice fields of Peninsular Malaysia. This study suggested that rice fields have great potential in providing feeding grounds for land birds and waterbirds. Although rice fields do not have complex vegetation, their unique landscapes due to farming activities attract many bird species (Golet et al. 2018). Bird taxa found in rice fields are significantly different from natural habitats, making the existence of rice fields vital to bird diversity in Peninsular Malaysia. Species richness becomes more prominent during the migratory season because rice field habitats play an important role as foraging grounds and stopover areas for many migratory birds. Hence, future studies are suggested to examine the foraging niche of waterbirds in rice fields to discover more details on the role of rice fields as foraging habitat.

Conservation effort and management should be initiated through bird censuses from the large granary areas to the isolated rice fields in Peninsular Malaysia. This is important to provide an overview of the current information on bird status and population estimate. Information on bird diversity in rice fields can be used for sustainable development and to improve management and conservation strategies of rice field areas in Peninsular Malaysia.

\section{ACKNOWLEDGEMENTS}

We thank the staff of Biological School (USM) for assistance in the field. Transportation was provided by the School of Biological Sciences, USM. The first author was supported by MyBrain 15 from Ministry of Education, Malaysia.

\section{REFERENCES}

Acosta, M., Mugica, L., Blanco, D., López-Lanús, B., Dias, R.A., Doodnath, L.W. \& Hurtado, J. 2010. Birds of rice fields in the Americas. Waterbirds 33(1): 105-122.

Amano, T., Kusumoto, Y., Tokuoka, Y., Yamada, S., Kim, E.Y. \& Yamamoto, S. 2008. Spatial and temporal variations in the use of rice-paddy dominated landscapes by birds in Japan. Biological Conservation 141(6): 1704-1716.

Aratrakorn, S., Thunhikorn, S. \& Donald, P.F. 2006. Changes in bird communities following conversion of lowland forest to oil palm and rubber plantations in southern Thailand. Bird Conservation International 16(01): 71-82.

Bevilacqua, S., Fraschetti, S., Terlizzi, A. \& Boero, F. 2009. The use of taxonomic distinctness indices in assessing patterns of biodiversity in modular organisms. Marine Ecology 30(2): 151-163.
Clarke, K.R. \& Warwick, R.M. 2001. A further biodiversity index applicable to species lists: Variation in taxonomic distinctness. Marine Ecology Progress Series 216: 265-278.

Department of Statistics. 2015. Selected agricultural indicators, Malaysia 2015. https://www.statistics.gov.my/index. $\mathrm{php} ? \mathrm{r}=$ column/cthemeByCat\&cat $=72 \&$ bul_id=bnR4ZFJ nbXVOQmt6TDhNNmh3M0Y5dz09\&menu_id=Z0VTZ GU1UHBUT1VJMFlpaXRRR0xpdz09. Accessed on 18 September 2016.

Department of Statistics. 2013. Paddy statistics of Malaysia 2013. http://www.doa.gov.my/c/document library/get_file?uuid=cef $1 \mathrm{fc} 5 \mathrm{~b}-0 \mathrm{adf}-437 \mathrm{~d}-\mathrm{a} 80 \mathrm{e}-$ f3136ee8b968\& groupId=358510. Accessed on 19 September 2016.

Ellingsen, K.E., Clarke, K.R., Somerfield, P.J. \& Warwick, R.M. 2005. Taxonomic distinctness as a measure of diversity applied over a large scale: The benthos of the Norwegian continental shelf. Journal of Animal Ecology 74: 1069-1079.

Elphick, C.S. 2008. Landscape effects on waterbird densities in California rice fields: Taxonomic differences, scaledependence, and conservation implications. Waterbirds 31(1): 62-69.

Elphick, C.S. \& Oring, L.W. 2003. Conservation implications of flooding rice fields on winter waterbird communities. Agriculture, Ecosystems \& Environment 94(1): 17-29.

Fujioka, M., Don Lee, S., Kurechi, M. \& Yoshida, H. 2010. Bird use of rice fields in Korea and Japan. Waterbirds 33(sp1): 8-29.

Ginny-Ng, S.L., Senik, M.S., Zubaid, A. \& Davison, G.W.H. 2005. A comparison of bird fauna of a forest fragment and a contiguous forest: Lessons for avian conservation. Malayan Nature Journal 57(2): 209-220.

Golet, G.H., Low, C., Avery, S., Andrews, K., McColl, C.J., Laney, R. \& Reynolds, M.D. 2018. Using ricelands to provide temporary shorebird habitat during migration. Ecological Applications 28(2): 409-426.

Guerrero, I., Morales, M.B., Oñate, J.J., Aavik, T., Bengtsson, J., Berendse, F., Clement, L.W., Dennis, C., Eggers, S., Emmerson, M., Fischer, C., Flohre, A., Geiger, F., Hawro, V., Inchausti, P., Kalamees, A., Kinks, R., Liira, J., Meléndez, L., Pärt, T., Thies, C., Tscharntke, T., Olszewski, A. \& Weisser, W.W. 2011. Taxonomic and functional diversity of farmland bird communities across Europe: effects of biogeography and agricultural intensification. Biodiversity and Conservation 20(14), 3663-3681.

Kelly, J.P., Stralberg, D., Etienne, K. \& McCaustland, M. 2008. Landscape influence on the quality of heron and egret colony sites. Wetlands 28(2): 257-275.

King, S., Elphick, C.S., Guadagnin, D., Taft, O. \& Amano, T. 2010. Effects of landscape features on waterbird use of rice fields. Waterbirds 33(sp1): 151-159.

Leonard, D.R.P., Clarke, K.R., Somerfield, P.J. \& Warwick, R.M. 2006. The application of an indicator based on taxonomic distinctness for UK marine biodiversity assessments. Journal of Environmental Management 78(1): 52-62.

Lourenço, P.M. \& Piersma, T. 2009. Waterbird densities in South European rice fields as a function of rice management. Ibis 151(1): 196-199.

Mansor, M.S. \& Sah, S.A.M. 2012. The influence of habitat structure on bird species composition in lowland Malaysian rain forests. Tropical Life Sciences Research 23(1): 1-14. 
Masero, J.A., Santiago-Quesada, F., SÁnchez-GuzmÁn, J.M., Villegas, A., Abad-GÓmez, J.M., Lopes, R.J., Encarnação, V., Corbacho, C. \& Morán, R. 2010. Long lengths of stay, large numbers, and trends of the Black-tailed Godwit (Limosa limosa) in rice fields during spring migration. Bird Conservation International 1(-1): 1-13.

Mohd-Taib, F.S. \& Kamaruddin, H.A. 2018. The rice-growing cycle influences diversity and species assemblages of birds in the paddy field ecosystem in East Peninsular Malaysia. Pertanika Journal of Tropical Agricultural Science 41(4): 1-16.

Natuhara, Y. 2013. Ecosystem services by paddy fields as substitutes of natural wetlands in Japan. Ecological Engineering 56: 97-106.

Noramly, G. \& Kumar, K. 2005. Avifaunal observations from Perlis State Park, Wang Burma, Perlis. Malayan Nature Journal 57(3): 279-295.

Nur Munira, A., Nurul Salmi, A.L., Shahrul Anuar, M.S., Mohd Abdul Muin, M.A., Amirrudin, A. \& Nur Juliani, S. 2014a. Diversity and temporal distribution of birds in ricegrowing landscape, Northern Peninsular Malaysia. Sains Malaysiana 43(4): 513-520.

Nur Munira, A., Nurul Salmi, A.L. \& Muhd Hakim, S. 2014b. Use of rice fields by raptors in Northern Peninsular Malaysia. Ela Journal 3(2): 5-14.

Nur Munira, A., Nurul Salmi, A.L., Shahrul Anuar, M.S., Mohd Abdul Muin, M.A., Nur Juliani, S. \& Nurul Liyana, K. 2011. Avian diversity and feeding guilds in a secondary forest, an oil palm plantation and a paddy field in riparian areas of the Kerian River basin, Perak, Malaysia. Tropical Life Sciences Research 22(2): 45-64.

Pearlstine, E.V., Mazzotti, F.J. \& Kelly, M.H. 2006. Relative distribution and abundance of wintering raptors in agricultural and wetland landscapes of south Florida. Journal of Raptor Research 40(1): 81-85.

Razafimanjato, G., Sam, T. \& Thorstrom, R. 2007. Waterbird monitoring in the Antsalova Region, Western Madagascar. Waterbirds 30(3): 441-447.

Rogers, S.I., Clarke, K.R. \& Reynolds, J.D. 1999. The taxonomic distinctness of coastal bottom-dwelling fish communities of the North-east Atlantic. Journal of Animal Ecology 68(4): 769-782.
Smith, R.G. 1995. Altitudinal survey of birds in Belum and Temenggor, Hulu Perak, Malaysia. Malayan Nature Journal 48: 387-395.

Sundar, K.S.G. \& Subramanya, S. 2010. Bird use of rice fields in the Indian Subcontinent. Waterbirds 33(sp1): 44-70.

Takahashi, M. \& Ohkawara, K. 2007. Breeding behavior and reproductive success of Grey-headed Lapwing Vanellus cinereus on farmland in central Japan. Ornithological Science 6(1): 1-9.

Warwick, R.M. \& Clarke, K.R. 1995. New 'biodiversity' measures reveal a decrease in taxonomic distinctness with increasing stress. Marine Ecology Progress Series 129: 301-305.

Wood, C., Qiao, Y., Li, P., Ding, P., Lu, B. \& Xi, Y. 2010. Implications of rice agriculture for wild birds in China. Waterbirds 33(sp1): 30-43.

Zainul-Abidin, M.K., Mohd-Taib, F.R. \& Md-Nor, S. 2017. Distribution and habitat selection of the Asian Openbill (Anastomus oscitans) in Peninsular Malaysia. Malayan Nature Journal 69(3): 169-181.

Nur Munira Azman*, Shahrul Anuar Mohd Sah \& Nik Fadzly

N Rosely

School of Biological Sciences

Universiti Sains Malaysia

11800 USM, Pulau Pinang

Malaysia

Amirrudin Ahmad

School of Marine and Environmental Studies

Universiti Sains Malaysia

21030 Kuala Terengganu

Terengganu Darul Iman

Malaysia

*Corresponding author; email: munirazman86@gmail.com

Received: 1 August 2018

Accepted: 11 June 2019 